\title{
What We Can Learn From Literary Authors
}

\author{
Alberto Voltolini ${ }^{1}$ (1) \\ Received: 13 October 2020 / Accepted: 13 April 2021 / Published online: 3 May 2021 \\ (c) The Author(s) 2021
}

\begin{abstract}
That we can learn something from literature, as cognitivists claim, seems to be a commonplace. However, when one considers matters more deeply, it turns out to be a problematic claim. In this paper, by focusing on general revelatory facts about the world and the human spirit, I hold that the cognitivist claim can be vindicated if one takes it as follows. We do not learn such facts from literature, if by "literature" one means the truth-conditional contents that one may ascribe to textual sentences in their fictional use, i.e., in the use in which one makes believe that things unfold in a certain way. What we improperly call learning from literature amounts to knowing actually true conversational implicatures concerning the above facts as meant by literary authors. So, in one and the same shot, we learn both a general revelatory fact and the fact that such a fact is meant via a true conversational implicature by an author. The author draws that implicature from the different truth-conditional content a sentence possesses when the sentence is interpreted in a fictional context, meant as Kaplan's (1989) narrow context, i.e., a set of circumstantial parameters (agent, space, time, and world).
\end{abstract}

Keywords Literary sentences $\cdot$ Literary authors $\cdot$ Cognitivism $\cdot$ Propositional knowledge $\cdot$ Conversational implicature

\section{Introduction}

That we can learn something from literature, as cognitivists claim, seems to be a commonplace. However, when one considers matters more deeply, it turns out to be a problematic claim. In this paper, by focusing on general revelatory facts about the world (broadly meant, in order to include even facts about its significance) and the human spirit, I hold that the cognitivist claim can be vindicated if one takes it as follows. We do not learn such facts from literature, if by "literature" one means the truth-conditional contents that one may ascribe to text-constituting sentences in

Alberto Voltolini

alberto.voltolini@unito.it

1 Department of Philosophy and Education Sciences, University of Turin, Turin, Italy 
their fictional use, i.e., the use in which one makes believe that things unfold in a certain way. What we improperly call learning from literature amounts to knowing the above general revelatory facts matching actually true conversational implicatures as meant by literary authors. So, in one and the same shot, we learn both a general revelatory fact and the fact that such a fact is meant via a true conversational implicature by an author. The author draws that implicature from the different truthconditional content a sentence possesses in its fictional use, hence when the sentence is interpreted in a fictional context, meant as a narrow context (Kaplan, 1989), i.e., the set constituted by four circumstantial parameters (agent, space, time, and world). ${ }^{1}$ Thus, we properly learn something not from literature as such, but from literary authors. ${ }^{2}$

The architecture of this paper is as follows. In Section 1, I outline the main problem for cognitivism, by exploiting the so-called minimal contextualism about fiction that appeals to narrow fictional contexts. In Section 2, I consider an interesting way out of the problem proposed by Garcia-Carpintero (2013, 2016, 2019), which I think is, at least partly, on the right track. In Section 3, I then articulate my own solution to the problem, which, unlike Garcia-Carpintero's, is based only on cancellable conversational implicatures. In Section 4, I try to assess some of the issues my solution must deal with.

\section{The Problem}

That we can learn something from literature (in a propositional sense of knowledge) seems to be a commonplace that cognitivists on this issue rely on. Indeed, a simple-minded reason as to why one must endorse cognitivism may be why should we engage with literature, if we could not extract from literary works not only some practical truths about how to improve some of our abilities, i.e., some form of knowing-how, but also some propositional truths, i.e., some form of knowing-that? ${ }^{3}$

\footnotetext{
${ }^{1}$ I here assume that when fictionally used, a sentence has a definite fictional truth-conditional content. One may put this assumption into doubt if one believes that whatever a sentence fictionally says is a matter of hermeneutic interpretation. Clearly enough, this belief is hard to maintain as regards any fictionally used sentence. If while reading a Doyle's novel one bumps into sentence (5) below, it is hard to believe that in its fictional use (5) has no definite fictional truth-conditional content: (5) is fictionally true iff the individual names "Holmes" is a detective in the world of the novel. But for some sentence so used, the indefiniteness problem may be a real one. For more on this cf. Everett (2013, pp. 36-37, 100-102).

2 Throughout the paper, by a literary author I mean the real producer of a sentence fictionally used. As we will see, I cash out a fictional use of a sentence in terms of the fact that the sentence is paired with a certain fictional narrow context, a set-theoretical entity made at least of four parameters: agent, space, time, and world. As such, the real producer of a fictionally used sentence may differ from the agent of that context, the fictional agent. Yet in some particular cases, the two may concide, namely, when first, the fictional agent coincides with the fictional author, an idealized story-teller that some (e.g., Currie 1990) postulate as the story's third-person narrator, and second, the fictional author coincides with the real producer, who counts as the story's implied author (Currie 2010). For more about this, cf. Voltolini (2021).

${ }^{3}$ More radically, even the kind of knowing-how that concerns ways for human beings to be or behave in certain situations may be reduced to a form of knowing-that (Engel, 2016).
} 
To start with, a caveat. As Searle (1975, p. 319) originally underlined, the relationship between fiction and literature is complicated: there may be bits of literature that are not fictional, as well as fictional works that are not literary. Yet by talking of "literature" I here limit myself to deal with textual sentences in their fictional use, i.e., as used by an author in order to make-believe that things unfold in a certain way, or that a later audience also makes when repeating that form of make-believe (Kroon and Voltolini 2018).

Moreover, I want to be clear from the outset that the propositional truths, or facts, that must be our concern when we wonder whether we learn something from literature are general revelatory facts about the world (broadly meant, in order to include even facts about its significance; from now onwards, I will take this specification for granted) and the human spirit (cf. also Reicher, 2012, p. 114). They may therefore include general moral truths (Gibson, 2007; Nussbaum, 1990), or even truths about our souls or ourselves more in general (Currie, 1998). These sorts of truths are what, at the very beginning of this debate in modern times, the cognitivist Weitz (1943) labeled second-order meanings of sentences belonging to a literary text. ${ }^{4}$ He gave the three following examples of second-order meanings of sentences belonging to Richard Wright's Native Son: ${ }^{5}$

a) That individual freedom is still an abortive ideal in America because our social injustices cancel out individual development;

b) That socialist reconstruction is the only way out of the present inhumanities of our society;

c) That the only freedom left to modern man is the freedom to destroy, first others about you and finally yourself (Weitz, 1943, 344-346).

First of all, note that such propositional truths have not eo ipso to do with facts that add value to a literary work in a properly aesthetic or ethical sense. For Weitz (1943, 345-346), only (c) accrues such a value. ${ }^{6}$ Knowing the general facts he talks about has to do with the factors that make the relevant textual sentences importantly revealing as regards the world or the human spirit, which may be one of the reasons - certainly not the only one - why we read literature.

\footnotetext{
${ }^{4}$ I stick to sentence cognitivism, i.e., the kind of cognitivism holding that we learn something from individual sentences of a literary text. Notoriously, one may also be a work cognitivist, holding that we learn something from a literary work as a whole. For both options, cf. Reicher (2012). Yet since in my account a literary work is nothing but an ordered collection of (possibly related) sentences in their fictional use, I take the second form of cognitivism as derivative from the first. If this dependence holds, then even Weitz (1943), who is sometimes taken as a sustainer of work cognitivism, can be suitably reinterpreted as a sustainer of sentence cognitivism. Indeed, he explicitly said (1943, pp. 344-345) that (a), (b), and (c) are implied just from some sentences in the relevant work.

5 Provided that they are examples of actual truths, as I will indeed assume.

6 Some anticognitivists more radically claim that the value of a literary work is unaffected by such truths. For that value depends on the mode in which the work's theme is presented (Lamarque and Olsen 1994). Granted, this last claim is controversial. For it presupposes that in a literary work, there is a rigid separation between theme and truth (Gaut 2005; Kivy 2011; Rowe 1997).
} 
Hence, moreover, in talking about what we learn from literature I am not interested in assessing many other candidate facts that may come to mind when talking about what one can learn from literature. To begin with, I rule out the issue of whether what we learn from literature are those propositional contents that constitute a literary story, the contents that are expressed by sentences that are embedded in parafictional sentences of the form "in story S, p" (Bonomi, 2008), as some weak cognitivists claim (Barbero, 2017). This is to say, I am not interested in the claim that if a story $S$, e.g., says that there are unicorns, one learns that in $S$, there are unicorns. $^{7}$

Granted, a weak cognitivist may take that sort of knowledge to be a more substantial form of knowledge, by taking it as a sort of counterfactual knowledge based on imaginative projection. In knowing that in a certain story something is the case, we know how things would unfold if we were in such an unactual situation, the situation affecting the fiction's protagonists (Barbero, 2017; Currie, 1998). For example, by knowing that in the Holmes stories Holmes is a cocaineaddicted who solves a lot of baffling crimes, we know that if we were in Holmes' shoes, we would solve a lot of baffling crimes, but by being addicted to cocaine. In Putnam's words, "I learn [...] to see the world as it looks to someone who is sure that hypothesis is correct. I see what plausibility that hypothesis has; what it would be like if it were true; how someone could possibly think that it is true" (Putnam, 1976, p. 488).

However, I wonder whether this knowledge of a possibility (Putnam, 1987) really amounts to a kind of general revelatory knowledge. Consider jokes, which are a paradoxical form of fiction squeezed into mini-stories. What kind of general revelatory knowledge do I attain if I know that, if I put myself in the shoes of some sort of deviant person, something extremely odd would occur? For example, what sort of general revelatory knowledge do I attain if I know that, if I put myself in the shoes of someone who shot an elephant in his pajamas, I would be ignorant as to how it got into such pajamas (to stick to the famous Groucho Marx joke)?

Besides, I also set aside the kind of, typically singular, propositional truths that some other weak cognitivists may say we learn from literature in using a literary text as a faithful map of the actual world. For example, some such cognitivists say that in reading Conan Doyle's Sherlock Holmes novels, one learns a lot about the urban geography of Victorian London, e.g., that Baker Street is nearer to Paddington than to Waterloo. ${ }^{8}$

\footnotetext{
7 Some have criticized this claim (Huemer 2007). Incidentally, the claim holds in general, independently of whether $S$ is a fictional story. From learning that, say, in the Ptolemaic theory the Sun moves, we learn nothing from astronomy, we learn how that theory is articulated or at most what Ptolemaics believed.

8 According to Friend (2014), we can be competent enough with a literary genre, or with an author or parts of her work, that we manage to draw apt beliefs from fiction, i.e., beliefs that are true in virtue of that competence. Yet I am uncertain whether any such appeal to competence explains why one should draw apt beliefs from fiction. People competent in a fictional genre - say, detective stories - may still be unable to draw such beliefs from it. For they may be led to acquire false beliefs that prevent them from drawing apt beliefs. To stick to a famous example from the Holmes novels, which are paradigmatic cases of detective stories, people competent in that genre may believe that Russell's vipers do climb ropes, which is however a falsity due to Doyle's ignorance of those snakes' biology.
} 
Granted, as regards both cases, I do not want to deny that one may learn these kinds of things from literature. But neither are the general revelatory sort of things one can learn from it. Learning from story $S$ that in that story there are unicorns and from the Holmes novels that Baker Street is nearer to Paddington than to Waterloo (to stick to Lewis' [1978, p. 268] famous example) certainly does not contribute to explaining why we read such works, or literature more in general.

Yet anticognitivists on this issue, people who deny that literature provides a propositional knowledge (ideally starting from Russell, 1940), reject the above commonplace. For some of them, either what we can grasp from literature is rather trivial, or it does not amount to learning, for the beliefs one obtains from literature are not warranted (Stolnitz, 1992). For others of them, more radically, fictional works contain only falsehoods or at least untrue statements, because they contain no reference to the actual world (Diffey, 1995; Frege, 1892). Since one can only learn something from (propositional) truths, it trivially follows that one can learn nothing from such works.

In Section 4, I will examine the moderate anticognitivist concern. For the time being, I just want to stress that there is a grain of truth in the anticognitivist radical concern. For if we limit ourselves to considering the fictional use of literary sentences, anticognitivism seems to be justified. For sentences so used are often actually untrue - they can turn out to be actually either false or neither true nor false, depending on the favorite theory of reference (say, a nonFregean vs. a Fregean one) one espouses, even if they are fictionally true. Thus, in any case, we can learn nothing from them.

We can easily see this point if we consider a fictionally used literary sentence as a sentence obtaining a truth-conditional interpretation in a fictional context (Recanati, 2000; Voltolini, 2006, 2016). Following Predelli, 2005, by" fictional context" I mean a particular narrow context (Kaplan, 1989), i.e., a set whose members are certain circumstantial parameters: an agent, a place, a time, and a world of interpretation, in this case, the world of the fiction. ${ }^{9}$ According to this minimal form of contextualism about fiction - minimal contextualism for short - first, a fictionally used sentence receives a truth-conditional content in the very same sense as an indexical sentence, i.e., a sentence containing indexical expressions such as demonstratives and pronouns (e.g., "that's heavy" or "I am American"), notoriously receives it, namely, by pairing it with a certain narrow context. Second, just as an indexical sentence may receive different truth-conditional contents depending on the different narrow contexts it is paired with, the same happens with a fictionally used sentence. Indeed, when so used, a sentence is truth-conditionally interpreted in a narrow fictional context. As such, it is fictionally true iff in the world of that context, this time taken as the circumstance of evaluation for the sentence so interpreted, things unfold as it says in that context. Yet this says nothing as regards the truth-conditions the

\footnotetext{
9 There is a wide debate on whether a world of fiction is a fictional world in a sense that is irreducible to that of a possible world. Following Predelli (1997), I will skip this debate by simply considering a world of fiction as a semantically required parameter of a fictional context that also works as a circumstance of evaluation for a sentence interpreted in that context.
} 
sentence has if it is interpreted in a narrow real context, i.e., a context whose world is the actual world; ditto for the truth-value the sentence so interpreted has when evaluated in the actual world, this time taken as the circumstance of evaluation for the sentence so interpreted. Thus, from the fact that the sentence, when interpreted in a narrow fictional context, is fictionally true, we cannot actually learn anything. For in this respect its evaluation in the actual world, when it is interpreted in a narrow real context, is irrelevant.

To see the problem, consider to begin with a narrow possible context, i.e., a context of interpretation whose world is a merely possible world. Take a sentence truthconditionally interpreted in that context, say:

(1) Smith is a philosopher fond of mosquitos.

Let us assume that "Smith" is a name that actually refers to nothing, but that it refers to an individual existing in the merely possible world of the possible context in question. Interpreted in that context, (1) is true when evaluated in that world of that context iff that individual is a philosopher fond of mosquitos there. Granted, from (1) so interpreted one can infer that in that world the following existential generalization is also true:

(2) Some philosophers are fond of mosquitos.

Yet when (1) is truth-conditionally interpreted in a narrow real context, a context whose world is the actual world, where "Smith" refers to nothing, (1) is untrue when evaluated in the actual world itself. Depending on one's favorite theory of reference, the sentence is actually either false or neither true nor false. Thus, from (1) so interpreted we cannot infer that in the actual world (2) is true. Maybe it is - suppose that there actually is a weird philosopher fond of mosquitos, say me! - but this cannot be inferred from (1) so interpreted. Likewise, if we truth-conditionally interpret (1) in the above possible context, we can certainly infer that (2) is true in that world as well, but we cannot infer that (2) is actually true. Thus, from the fact that (1) is true when interpreted in a narrow possible context, we cannot learn what (2) says.

The foregoing must seem rather trivial. Yet suppose now that the relevant narrow context of interpretation is a fictional context, for its world is a fictional world. Mutatis mutandis, you can draw the same conclusion as before. For example, from the fact that, when truth-conditionally interpreted in a narrow fictional context whose world is the world of Anna Karenina,

(3) Anna's family is unhappy in its own way, and so are other families close to her

is notoriously true when evaluated in that world, we can fictionally infer by induction the universal generalization:

(4) Each unhappy family is unhappy in its own way.

as being true in the very same world. (3) is actually untrue, for "Anna" refers to nothing in a narrow real context whose world is the actual world. So, not only when 
it is interpreted in a narrow real context, but also when it is interpreted in the relevant narrow fictional context, we cannot infer (4) as being actually true, i.e., true in the actual world of the narrow real context. Even though, in this particular case, (4) is certainly actually true. For it expresses the so-called Anna Karenina principle: "a deficiency in any one of a number of factors dooms an endeavor to failure" (https:// en.wikipedia.org/wiki/Anna_Karenina_principle). Hence, from (3) as truth-conditionally interpreted in a fictional context, we cannot learn what (4) actually truly says. In order for us to learn (4)'s actual truth from literature - and not from any other theoretically possible source - we should derive it from (3)'s fictional truth. But we cannot derive an actual truth from a fictional truth. ${ }^{10}$

To circumvent the above problem, a cognitivist may immediately reply that it only affects the fictional use of sentences. Yet, she may go on to say that such sentences can also be used nonfictionally, notably to state actual truths about the fiction itself. In this use, the internal metafictional use (Kroon and Voltolini 2018), ${ }^{11}$ sentences are elliptical for parafictional sentences of the "in story S, p"-form. For example, when a sentence like:

(5) Holmes is a detective

is nonfictionally used in this way, it is equivalent to the parafictional sentence:

(6) In the Holmes stories, Holmes is a detective.

Definitely, (6) is actually true for so the Holmes stories go. Thus, a cognitivist may conclude, we learn something from this use of literary sentences, which often involves actual truths, as in the case of (5) (hence, of (6)).

Yet the actual truths in question are not the premises from which we may derive the general revelatory truths one learns from literature. Instead, as we saw before, they can be seen as what we (perhaps unsubstantially) learn, as some weak cognitivists claim (Barbero, 2017).

\section{An Interesting Way Out}

At this point, a proposal emerges that preserves the point of cognitivism as such (Garcia-Carpintero, 2013, 2016, 2019). ${ }^{12}$ Not only ordinary factual truths, as some weak cognitivists claim, but also general revelatory truths about the world and the human spirit, as other cognitivists would have it, can be learned from literature. This

\footnotetext{
${ }_{10}$ Remember that we are dealing with a fictional world as a parameter for a narrow context of interpretation that also works as a circumstance of evaluation for a sentence interpreted in that context. As we saw, nothing would change if that world were a genuine possible world. It thus seems that we can hardly learn something from fiction just as we can hardly learn something from possibility.

11 In Currie's (1990) terminology, this is the metafictive use of such sentences.

12 This proposal originally occurred in Reicher (2012, pp. 121, 124-125).
} 
depends on the fact that a literary sentence can be used with a double meaning, in order to perform two different speech acts, a direct and an indirect one. For Garcia-Carpintero, just as in directly asking a question one may also indirectly make a request, in fictionally using such a sentence one directly performs a fiction-making, or fictionalizing, speech act in which one invites the reader to imagine something, yet one may also indirectly assert that very sentence by inviting the reader to believe something. This happens in two cases, namely, both when the fictional and the assertoric engagement with that sentence say the very same thing that is both fictionally and actually true, and when one asserts something that is actually true in fictionalizing something else that is merely fictionally true. ${ }^{13}$ In both cases, there is an indirect assertoric content that corresponds either to a noncancellable conversational implicature - a contextual entailment that depends on the speaker's intention and that may not be denied by the speaker herself in avowing that she has no such intention - or to a cancellable conversational implicature - another such contextual entailment that the speaker may instead deny. When the first form of implicature occurs, typically the fictional and the assertoric content are the same. ${ }^{14}$ When the second form of implicature occurs, the fictional and the assertoric content diverge.

In Garcia-Carpintero's account, the first case is what typically, but not exclusively, happens with historical novels, which aim to grasp factual truths over and above fictional ones. Consider the beginning of Alessandro Manzoni's historical novel The Betrothed, which in its fictional use also counts as a true description of a certain geographical area of Lombardy, Italy:

(7) That branch of the Lake of Como, which turns toward the south between two unbroken chains of mountains, presenting to the eye a succession of bays and gulfs, formed by their jutting and retiring ridges, contracts itself between a headland to the right and an extended sloping bank on the left, and assumes the flow and appearance of a river.

In fictionally using (7), says Garcia-Carpintero, one both directly fictionalizes what turns out to be a fictional truth, by inviting the reader to imagine something concerning Lombardy's geography, and indirectly asserts the very same thing which turns out to be also an actual truth - by inviting the reader to believe that very thing. This very same content, qua asserted, amounts to a noncancellable conversational implicature. As I just hinted, this situation may also occur also in nonhistorical novels. The famous aforementioned incipit of Leo Tolstoy's Anna Karenina is a case in point:

(8) All happy families are alike; each unhappy family is unhappy in its own way.

\footnotetext{
13 Gendler (2000, p. 76) calls the inferential process taking place in this case "narrative as factory.".

14 For Garcia-Carpintero (2019), the two contents may diverge even when a noncancellable conversational implicature occurs, if that implicature concerns the real settings of the story, as when one learns by reading the relevant bit of the Holmes stories how British people were dressed in the Victorian era. In actual fact, I am not sure whether there really are examples of this kind that do not fall under the second type of case, the one involving a cancellable conversational implicature.
} 
In fictionally using (8), one both directly fictionalizes what turns out to be a fictional truth, by inviting the reader to imagine something concerning the different fate of happy and unhappy families, and indirectly asserts the very same thing — which turns out to be also an actual truth - by inviting the reader to believe that very thing. Again, this very same content, qua asserted, amounts to a noncancellable conversational implicature.

Still in Garcia-Carpintero's account, the second case instead occurs when the fact that the uttered literary sentence has a fictional (truth-conditional) content serves for one to display a different assertoric content that aims at disclosing a general revelatory truth about the world or the human spirit. An example of this case occurs when in Mario Monicelli's movie The Girl with the Pistol, the main character of the movie, Assuntina Patané, utters:

(9) A real man must always try but a real woman must always defend herself

so as to make:

(10) Assuntina says "A real man must always try but a real woman must always defend herself"

fictionally used. In so using (10), one directly fictionalizes what turns out to be a fictional truth, by inviting the reader to imagine what, according to Assuntina, must be the sexually involving behavior of real men and real women. Yet one also indirectly asserts a different content that amounts to an actual truth, by inviting the reader to believe that the social condition of Sicilian women in the $60 \mathrm{~s}$ was rather problematic. (Monicelli's The Girl with the Pistol is one of the main examples of Italian satirical film comedies made in the $50 \mathrm{~s}$ and $60 \mathrm{~s}$. One of the movie's main aims is precisely to mock the mentality of Sicilian people at that time.) Thus, (10) is fictionally used to fictionalize a certain thing, which is fictionally true, in order however to assert a different thing, which is actually true. In this case, the assertoric content amounts to a cancellable conversational implicature. One may, indeed, add a comment to (10) and say that in fictionally using it, one had no intention whatsoever to mock any Sicilian people of that time.

This account has various merits. First, it reduces to the cases of (7)-(8) what according to Evans (1982) and Walton (1990) is generally the case as regards fictionally used sentences. For these authors, such sentences are fictionally used (and are normally fictionally true) in order to assert something that is actually true, thereby also having a content identical to that of internally metafictionally used sentences. Second, it explains in what way the truths that one learns from literature are implied truths, as originally stated by Weitz (1943, p. 344). The implication that is at stake indeed conforms to the general Gricean mechanism of conversational implicatures. One conveys something more than, or different from, what one (fictionally) says, by meaning a content either in a cancellable or noncancellable way. First, in the cases of (7), (8), and (10), the speaker seemingly violates a conversational maxim, the 
maxim of quality, since in their fictional use such sentences are just fictionally true. Yet second, since it is circumstantially evident that, possibly unlike other situations involving those very sentences (or similar ones), by so using them the speaker wants to stick to the general conversational principle of cooperation - in using those sentences, she does not want to deceive anyone, she instead wants to present a sort of parable - this evidence can be explained by ascribing to the speaker her conveying something different from what she (fictionally) says, by meaning an(other) content in a cancellable or in a noncancellable way.

Now, I think Garcia-Carpintero is on the right track. For, as we will see in the next section, my account is a development of his ideas as regards the second case that sentences like (10) display. For this case paradigmatically presents the general revelatory facts that have to be learned from literature.

Yet my qualms are with the first case displayed by sentences like (7) and (8). A first qualm is that conversational implicatures are hardly noncancellable. Noncancellability normally features conventional implicatures - entailments due to the conventional meaning of the expressions used in the relevant sentences - yet there is no trace of such implicatures here. However, this qualm is minor, for various people have claimed that there are other cases, admittedly atypical, of noncancellable yet conversational implicatures. ${ }^{15}$ Yet, secondly, a conversational implicature standardly calls into the fore an assertoric content different from the truth-conditional content, in this case fictional, which is said by the uttered literary sentence. In stating that a certain girl married and got pregnant, one says that she both got married and pregnant, but one conversationally means, in a so-called generalized conversational implicature, that she first got married and then got pregnant. Yet in (7)-(8), the fictional and the assertoric content that is at stake with them is respectively allegedly the same. 16,17

Interestingly enough, the minimal contextualism I set out in the previous section allows me to provide an alternative treatment of the cases that (7)-(8) present. In such cases, the idea that one and the same content is mobilized in being both

${ }^{15}$ As resumed in Åkerman (2015). In (2019), Garcia-Carpintero provides examples of such implicatures.

${ }^{16}$ Garcia-Carpintero (2019) would deny this, by taking in the case of (7)-(8) what is fictionally said as an invitation to imagine a general content, and what is actually asserted as an invitation to believe a singular content involving real individuals. Yet I wonder whether this denial simply depends on GarciaCarpintero's specific view (2013) concerning what one is prescribed to imagine in the fictional use of a sentence. For it is more natural to say that in the case of (7)-(8) what is fictionally said is exactly the same as what is asserted, namely, a singular content involving real individuals.

${ }^{17}$ If there really are examples of noncancellable conversational implicatures where however the fictional and the assertoric content diverge (see fn.14), they can also be accommodated by the minimally contextualist account I will further articulate below. For in such examples, the fictional truth-conditional content of a fictionally used sentence fictionally entails another such content, which however is the same as the actual truth-conditional content of another sentence in its historical use aimed at describing (the relevant bit of) the story's settings. Fictionally using "Holmes wears a hat with ear flaps" has a fictional truth-conditional content that fictionally entails that such a hat was à la mode for men in the Victorian era. This is the content that another sentence, "Hats with ear flaps were à la mode for men in the Victorian era," has as its actual truth-conditional content when historically used. More in general, the phenomenon of importation of reality into fiction ("the Reality Assumption," Friend 2017) falls under this very model. Fictionally truly saying "Holmes more readily walks from Baker Street to Paddington than to Waterloo" fictionally entails that Baker Street is nearer to Paddington than to Waterloo. For this is inherited as a fictional truth while also being an actual truth said by a matching sentence in its historical use. 
fictionally and nonfictionally involved with such sentences is better accounted for by claiming not that such a content is doubly mobilized by distinct speech acts in the same use of a literary sentence, but that such content is mobilized twice by different uses of that sentence, a fictional and a historical use of it. The historical use of a literary sentence is another nonfictional use of it, over and above the internal metafictional one, which can be captured by pairing the sentence with a certain narrow real context, the narrow historical context. Let me explain.

As I said before, in the internal metafictional use of a literary sentence, namely, when the sentence amounts to the corresponding parafictional sentence of the "in story S, p"-form, both (7) and (8) are actually true, but just in the very same, certainly nonrevelatory, sense in which any other literary sentence can be actually true. It is actually but nonrevelatorily true that in The Betrothed, the lake of Como has that particular configuration, and it is actually but nonrevelatorily true that in Anna Karenina happy and unhappy families are different as to their fate. Yet in the historical use, both (7) and (8) are actually true in their having exactly the same content as when they are fictionally used. Indeed, the historical and the fictional use of a literary sentence respectively correspond to the fact that such a sentence effectively receives the same truth-conditional meaning both when paired with a certain narrow real context, the narrow historical context, and when paired with a narrow fictional context. Indeed, relying on narrow contexts of interpretation à la Predelli, 2005 clarifies this point. A sentence like (7) may be fictionally true once, when it is fictionally used, it is truth-conditionally interpreted in the narrow fictional context whose world is The Betrothed 's world and is positively evaluated in that world. But it is also actually true once, when it is historically used, it is truth-conditionally interpreted in a narrow real context, the narrow historical context, whose world is the actual world and is positively evaluated in our world. Now in both contexts, (7) happens to have the very same truth-conditional content and is both fictionally and actually true: both in The Betrothed 's world and in the actual world, the geography of that portion of Lombardy is as (7) says. Mutatis mutandis, the same holds for (8).

Granted, one may say that if one puts the world determination in the constitution of the relevant truth-conditional content, as the minimally contextualist account should suggest, then the fictional and the historical use of a sentence " $p$ " truth-conditionally diverge. For in the first case, that sentence "p" says that in the world of the fiction, $\mathrm{p}$, while in the second case it says in the actual world, $\mathrm{p}$.

Yet the minimal contextualist is not forced to make this move. For, as Recanati (2000) has stressed, appealing to contexts of interpretation does not make one eo ipso commit to an Austinian semantics, according to which "the complete content of an utterance is an Austinian proposition consisting of two components: the fact which the utterance explicitly says (the proposition it expresses, in the standard sense) and the situation which that fact or proposition concerns" (2000, p. 64). And pour cause. For if a sentence in those uses respectively expressed the above different contents including its different world parameters (the world of the fiction, the actual world), it would have its truth-value necessarily, instead of having it contingently as it seems. Even if in its historical use such a sentence is true in the actual world, it might have been false in other worlds; ditto for the sentence in its fictional use. 
Now, this minimally contextualist way of accounting for the fact that sentences like (7)-(8) respectively have the same truth-conditional content both in a fictional and in a real context is not only an alternative to Garcia-Carpintero's account, but it also has an independent merit. Indeed, it enables one to explain why such sentences may have the same truth-conditional content both in a narrow fictional and in a narrow real context and yet have different truth-values when evaluated with respect to the world of the fiction and to the actual world, typically by being fictionally true and actually false. For they are true in their fictional use, but false in their historical use. One may call this the "Rolex" problem, by pointing to the anecdotal implausibility of so-called colossal films in which it was fictionally true of, say, ancient Roman soldiers what was obviously historically false, namely, that they wore Rolex watches on their wrists (just because the actors impersonating them had forgotten to take them off). Consider, e.g., the difference between these two sentences:

(11) Marcus Aurelius led the Roman troops against the Germans.

(12) Marcus Aurelius died immediately after his final battle with the Germans.

(11) is just like (7)-(8). For not only does it keep the very same truth-conditional content both when it is interpreted in the narrow fictional context whose world is the world of Ridley Scott's The Gladiator and when it is interpreted in a narrow historical context whose world is the actual world, but it is also evaluated as true in both cases. Now, (12) also keeps the very same truth-conditional content both when it is interpreted in the narrow fictional context whose world is The Gladiator 's world and when it is interpreted in a narrow historical context whose world is the actual world. Yet when evaluated with respect to the first world, The Gladiator 's world, it is true, it is fictionally true: in The Gladiator 's world, this is the way things go. Yet when evaluated with respect to the second world, the actual world, it is false, it is actually false: the Roman Emperor actually died one year after his final battle with the Germans.

Thus, we must drop Garcia-Carpintero's treatment of the first case that sentences like (7)-(8) (and also (11)) display. Yet, as I said before, his treatment sounds correct to me as regards the second case that sentences like (10) display. Let us now see how this way of putting things can be further developed.

\section{A New Solution}

To begin with, I want to claim that, as regards sentences like (10), to repeat:

(10) Assuntina says: "A real man must always try but a real woman must always defend herself"

Garcia-Carpintero is quite right. In its being fictionally true, a fictionally used sentence can also be employed in order to truly assert, via a conversational implicature, an implicated content that differs from the truth-conditional content it has in that use, hence in the relevant narrow fictional context of interpretation. This true implicated content is precisely one of the general revelatory truths about the world and the human spirit I pointed out at the beginning of this paper. 
This claim perfectly fits Grice's model as regards conversational implicatures. Firstly, as some have already pointed out (e.g., Popa-Wyatt, 2014, p. 134), Grice himself stated $(1989$, pp. 34, 53-54, 120) that one can conversationally imply something not only by saying something else but also by making as if one were so saying. This idea may sound problematic. Yet in the minimally contextualist account, it is perfectly intelligible, once this "making as if" is understood in terms of a fictional use of a sentence amounting to the fact that the sentence has a truth-conditional interpretation in a narrow fictional context of interpretation. So interpreted, the sentence says something in that context.

Secondly, the fact that the sentence is fictionally true in that use seemingly violates Grice's conversational maxim of quality, since fictional truth is no guarantee of actual truth. Since however there is no contextual reason to suppose that the speaker is parting company with Grice's conversational principle of cooperation, for she does not want to deceive her audience and wants instead to present a sort of parable, the tension is removed once the sentence so used is taken to implicate something more than, or different from, what it fictionally says. Indeed, the sentence is not only fictionally true in its fictional use, but it is also actually true, in the different assertoric content that is so implicated. Hence, what we immediately learn with respect to literature actually is that assertoric content, when true.

Finally, third, the implicature is a standard conversational implicature. (a) It is calculable, which is ordinarily taken to be a necessary feature of a conversational implicature. An audience grasps it by ideally engaging in an inferential process like the one sketched above and involving the idea that the speaker is abiding by the general co-operative principles of conversation, even if she seemingly violates a conversational maxim. In the case of (10), as I have just said, one may wonder why such a weird sentence, which seemingly violates the maxim of quality (there is no real Assuntina saying what she says in the movie), is fictionally used. Answer: because the author wants to convey the general revelatory fact that the social condition of Sicilian women in the $60 \mathrm{~s}$ was rather problematic, as negatively affecting their own mentality. (b) It is nondetachable: one might utter a sentence different from (10) but by fictionally using it with the same truth-conditional content, yet the implicature would nonetheless obtain. (c) It is cancellable. In our example, by appropriately disclaiming what was apparently implicated by the relevant utterance of (10) and is directly said by the different sentence:

(13) The social condition of Sicilian women in the $60 \mathrm{~s}$ was rather problematic

one may deny that such an utterance of (10) has the implicature that (13) directly says. Clearly enough, just as in other cases of cancellability, the subject most entitled to cancel the implicature is the sentence's original utterer; typically, the story's author. Unlike a conventional implicature, a conversational implicature is basically a matter of the intentions that are attributed to the relevant utterer, the story's author in this case. Thus, the story's author is ultimately entitled to say that she did not have the intentions on which the implicature relies. As regards (10), Monicelli, The Girl with the Pistol's director, is ultimately entitled to say that in his fictionally using (10), he does 
not conversationally implicate (13). As the movie's author, he is ultimately entitled to say that in uttering (10), he does not mean to assert, admittedly in an ironic mode, that the social condition of Sicilian women in the $60 \mathrm{~s}$ was rather problematic. ${ }^{18}$

Now, the fact that the author is ultimately entitled to cancel a conversational implicature shows that such an implicature is an authorial implicature. This has an important consequence for my account. Since, as I have just said, the implicated content, when actually true, amounts to a general revelatory fact, it is better to say that what we learn is something that is not from literature, but from literary authors. Indeed, we learn this fact neither from the fictional use, nor even from the internal metafictional use, of a literary sentence. We take it for granted that the truth-conditional contents for such uses have been respectively fixed, as if matters of interpretation regarding them had been settled. Once all this has been established, we learn the fact from the true conversational implicature that we draw from the fictional use of such a sentence.

In doing so, we acknowledge that the author is reliable in grasping the general revelatory fact about the world and the human spirit matching the true content of that implicature. As if we could not fail to recognize that the author has intuited that fact. But what counts is that, however it has been established to be so, the implicature is true, in order for us to learn the general revelatory fact in question. ${ }^{19}$

This way of putting things surely has an advantage. As I said at the very beginning, from Stolnitz, 1992 onwards, moderate anticognitivists have stressed that, even if it concerns general revelatory facts about the world and ourselves, what we learn from literature remains rather trivial. For it is something that we already know by other means. Thus, in its displaying fictional truths, literature is not the source of that knowledge; at most, it provides us with a belief whose sources, however, lie elsewhere. ${ }^{20}$ In the case of (10) (or (13) for that matter), we are definitely not forced to watch Monicelli's movie in order to know that the social condition of Sicilian women in the $60 \mathrm{~s}$ was rather problematic. It is something we already know by having read reports on Sicily, or maybe on Southern Europe in general, at that time.

Granted, this is not always the case. Sometimes at least, what we learn from literary authors is fresh news. Consider when the general revelatory fact that we learn has to do with the overall significance of a historical event. If we want to know what

\footnotetext{
18 There certainly are other accounts of conversational implicatures that trace them to normatively oriented rather than to intentionally oriented factors, such as the idea that the text itself elicits such an implicature to competent audiences (cf., e.g., Saul 2010). Yet, since I take work cognitivism as derivative upon sentence cognitivism (see fn.4), I take such accounts as not pertinent here.

19 The issue of what makes an author reliable insofar as she conveys truths that amount to general revelatory facts about the world and ourselves is epistemologically very interesting. For clearly, the author cannot gain her reliability as regards such truths from her being a testimony of empirical facts. One may suppose that the author has a sort of Erfahrung of the human spirit, as Wittgenstein $\left(2009^{4}:\right.$ II,xi§355) would have put it. Or she has a sensibility to grasp the sense of some world's vicissitudes, as manifested in a sort of Joyce-like epiphany (for Eco, this makes the case that what we learn from literature is truth, yet in a nonpropositional, but objectual sense: something like an illuminating event, precisely a Joycelike epiphany; cf. Paolucci 2017). Unfortunately, for reasons of space I cannot properly deal with this issue here. On this, cf. Reicher (2012, p. 123), Ichino and Currie (2017).

${ }^{20}$ As Green points out, literature is not what cognitivism would like, i.e., "a source of knowledge that crucially depends on its being fictional" (2017, p. 48). Carpintero himself seemingly acknowledges, at least partially, the point when he says that as to literature, "learning does not need to involve coming to believe new truths, but merely coming to be closer to the truth" (2016, p. 131n.36).
} 
the 68 revolution really was, better to read books such as Umberto Eco's Foucault's Pendulum rather than history treatises. But even if we already know the fact in question, we certainly do not know before reading a story that such a fact matches what its author meant, actually truly, in drawing a conversational implicature from her fictional use of the relevant literary sentence. For the author's intention, on which the relevant conversational implicature of such a fictionally used sentence relies, manifests itself in that reading. Before watching The Girl with the Pistol, we may certainly already know that the social condition of Sicilian women in the $60 \mathrm{~s}$ was rather problematic, but we do not also know that Monicelli thought so by mobilizing (10). Thus, if we accept that what we learn from literature is really what we learn from the relevant literary authors, there is always an aspect of novelty in such knowledge. For what we know is actually a conjunction: a certain general revelatory fact plus the fact that the literary author truly meant it. We may already know that general revelatory fact, such as the one directly and truly said by (13), but we do not certainly know yet that such a fact matches what an author meant in her true conversational implicature. Thus, even though we may be already acquainted with the relevant general revelatory fact via other means, what we surely learn as a novel thing is that fact as meant by the author. So, the fact that what we learn from literary authors is the above conjunction makes it the case that our knowledge is not trivial. For we learn not only the fact that verifies the implicature if true but also the fact that a certain author truly meant it.

This further entails that if we learned only what an author meant in asserting something via a conversational implicature, for that implicature is actually false, hence, it discloses no general revelatory fact, then we would not learn anything from literary authors. At most, we would learn something about literary authors themselves, namely, that they mean certain contents. For example, if by reading Story of $O$, notably some of its fictionally used sentences, one took it that Pauline Reage, its author, conversationally implicates from those sentences so used:

(14) Women like to be brutalized by men

this would not be something that we would learn from Reage. For that implicature is false. As regards women's psychology, Reage is not reliable, for she certainly does not disclose general revelatory facts about it. At most, we learn something about Reage's own psychology, notably what she thinks about intimate relationships between men and women. Put alternatively and synthetically: we can grasp a conversational implicature via a Gricean mechanism even if that implicature were actually false, but in that case, we would learn nothing from it. For one can learn, just as one can know, only what is actually true. ${ }^{21}$

\footnotetext{
${ }^{21}$ In (2010), Nanay defends a similar point by stressing that, in the paradigmatic cases of imaginative resistance, we fully imagine what is fictionally said in the fictional use of a sentence, but in certain cases, we refrain from imagining what the author conversationally implicates with it. As that resistance is indeed for him contextual, it may happen that, as regards an erotic novel such as Story of $O$, we manage to grasp a conversational implicature such as that directly said by (14), even if we would refrain from grasping it in the different context of a realistic tale.
} 


\section{Objections and Answers}

So far, so good. Yet it may now seem that the old problem we started out from arises again. In Section 1, we saw that from a fictional truth such (1) in its fictional use, no real entailment follows, i.e., an entailment concerning an actual truth holding in the actual world such as the one that (2) presents if it is actually true. How can things fare better when a conversational implicature, rather than an entailment, is at stake? In the Monicelli example, in its fictional use, (10) is fictionally true, for this is how things go in The Girl with the Pistol's world. Yet how can one derive from it a true conversational implicature such as that directly said by (13) holding of the actual, not of the fictional, world, so that we can learn something from it?

Appealing to the fact that one and the same agent entertains both the fictionalizing and the assertive speech act, as Garcia-Carpintero (2019) does, unfortunately does not help. For as I have just stressed, the truth that allegedly triggers the conversational implicature is a fictional truth holding in a fictional world. So at most, it would trigger a conversational implicature holding in that very world in which the very same yet fictional agent was involved, just as in the case of (1)-(2). In point of fact, this situation neutralizes the possibility Garcia-Carpintero appeals to, namely, the possibility for the real author, who originally uses the relevant literary sentence fictionally, to perform a fictionalizing speech act triggering an assertive speech act whose actual content is satisfied actually. Indeed, in order for a speech act with a certain content to arise out of entertaining another truth-conditional content within another speech act, both that act and that content must mobilize the same circumstance as the one involving the other content with the other speech act. Yet this is not the case if the truth-conditional content so entertained, along with its accompanying fictionalizing speech act, is fictional, while the alleged assertive speech act with its content that should arise out of such an entertainment is supposed to be actual. As Green (2017, p. 54) puts it, a fiction-maker actually performs a mere act of speech, rather than a proper fictionalizing speech act (see also Predelli, 2020, p. 37-38, 40).

Again, resorting to minimal contextualism and narrow contexts of interpretation makes this point vivid. The fictional agent of a narrow fictional context of interpretation may certainly conversationally implicate something in that context over and above what she there says. Consider Jane Austen's Emma. In the relevant narrow fictional context that has the world of Emma as its world, its agent — i.e., Emma's third-person narrator - utters, while referring there to Mr. Elton being in the room with Augusta Hawkins, Emma, and Harriet:

(15) She considered how peculiarly unlucky poor Mr. Elton was in being in the same room at once with the woman he had just married, the woman he had wanted to marry and the woman whom he had been expected to marry.

That agent says so in order to conversationally mock in that context Mr. Elton's affective confusion. Still in that context: 
(16) Mr. Elton is affectively unstable

might have directly said that conversational implicature. Now, the fictional agent's implicature with her utterance of (15) that (16) fictionally says is just as fictionally true as her saying (15) in the narrow fictional context, i.e., true in Emma's world. Yet all this does not enable $u s$, individuals of the actual world, to learn something from Jane Austen. In order for us to do so, we need a conversational implicature that is mobilized not by a fictional speech act of a fictional agent, but by the real author, i.e., Austen herself, and that is therefore actually, not fictionally, true. How can we achieve this result? ${ }^{22}$

Fortunately enough, appealing to narrow contexts not only makes the problem vivid but also provides a solution to it. What helps is the fact that the context of interpretation, i.e., the narrow context relevant to determining what is said by an utterance of a given sentence, its truth-conditional content, here differs from the context of utterance, the real context in which the sentence is effectively uttered (Predelli, 2005). Consider the original example Predelli, 1998 provided. In recording on an answering machine "I am not here now," one assumes that the indexical "now" is interpreted not with reference to the time of the context in which one utters that recording, but with reference to a different time, typically the later time in which the recorded message will be listened to by an intended audience. Likewise in our case, who is relevant in order to supply the uttered literary sentence with its truth-conditional content, the agent of the fictional context of interpretation may differ from the real utterer in the context of the utterance. As Currie (1990) holds, that contextual agent is a fictional narrator, i.e., the protagonist of the story that makebelievedly tells it in the first person, or even an ideal narrator, i.e., someone who enters into the fore at the periphery of the narrated scene (Predelli, 2017, 2020) as the contextual agent that pops up when nobody make-believedly tells the story in the first person. This typically happens with stories whose setting is a speechless or even mindless world (Currie, 1990). Instead, the real utterer is just the typically different real author of the relevant literary work. ${ }^{23}$

Once we distinguish in this way between contexts of utterance and contexts of interpretation, then, even if a sentence is both truth-conditionally interpreted and truly evaluated as regards a narrow fictional context mobilizing a fictional or even an ideal narrator as its agent, an actual conversational implicature from it may instead be traced back to the (typically different) real utterer of the sentence, the real author. This may indeed be a true implicature holding in the actual world. Therefore, from a fictionally true use of a sentence involving a fictional agent one may ascribe to the typically different real author a true conversational implicature holding in the actual world. $^{24}$

\footnotetext{
${ }^{22}$ Curiously enough, Predelli does not seem to see a similar kind of problem when, after having said that fictionally saying something may fictionally impart something else (such as that a tale's protagonist bears a certain name), he adds "much of what [the fictional narrator] fictionally imparts is something that we actually manage to entertain and negotiate" (2020, p. 29).

23 Granted, the real utterer of the context of utterance may coincide with the agent of the context of interpretation, for the real utterer is the same either as the fictional or as the ideal narrator. Yet if this were the case, it would be even simpler to trace the conversational implicature back to the real utterer.

24 Nanay (2010) draws a similar difference between a fictional use of a sentence and the conversational implicature one may draw from it as ascribed to its original real author.
} 
Interestingly enough, this move is not only not ad hoc, but it also occurs elsewhere. For not only does the distinction between a context of interpretation and a context of utterance obtain in many other cases having nothing to do with fiction, as we saw before with the answering machine example. But also, even from a sentence obtaining a certain truth-conditional content in a narrow nonfictional context of interpretation one draws a conversational implicature tracing back to the real speaker in the context of utterance.

Consider the following case. Suppose that an Italian translator of the famous extract from a speech by Donald Trump, "Why would Kim Jong-un insult me by calling me 'old,' when I would NEVER call him 'short and fat?' Oh well, I try so hard to be his friend - and maybe someday that will happen!" rendered the Italian translation of that extract as:

\section{(17) Io non lo chiamerei MAI 'basso e grasso’}

while, however, simultaneously raising her eyebrows. In that case, her facial gesture would make it clear that she - the real utterer of (17) — and not Trump himself - the agent of interpretation, what the Italian indexical "io" refers to in the above utterance of (17) — has conversationally implied something like:

(18) This guy [i.e., Trump] is bizarre.

For linking (17), interpreted as above, with that gesture may seem to violate the maxim of pertinence or even of that of mode. Yet no such violation arises once one captures the fact that, by abiding by the general conversational principle of cooperation, the real utterer of (17) wants to convey what (18) directly says. Clearly enough, this conversational implicature does not hold in the context of interpretation. By means of the original English sentence that (17) translates, Trump, the agent of the context of interpretation, does not want to convey that he considers himself bizarre. Instead, the implicature holds in the context of utterance. The real utterer of (17), the translator, wants to let us know that, although her job forces her to translate into Italian what Trump says in English, she does not share Trump's point of view about his relationship with the Korean dictator Kim Jong-un.

Interestingly enough, this move is generalizable in many other, literature-involving, cases. Typically, in these cases, we learn something that concerns the author's moral in a literary work, notably when parody and satire occur in that work, or we even learn that by means of that work, the author wants to (covertly) convey something that concerns herself.

For example, by virtue of the fact that the fictional agent says in The Clouds:

(19) Socrates moves to the ether and looks at the sun from above

Aristophanes, the real utterer of (19), intends to mock Socrates by actually implicating conversationally that he was a bullshitter. We learn this from Aristophanes if 
he is right. Or again, by virtue of the fact that the fictional agent says in Madame Bovary:

(20) Emma harbors idealistic romantic illusions

Gustave Flaubert, the real utterer of (20), conversationally implicates that he himself is such (as suggested by his famous motto "Madame Bovary c'est moi"). We learn this from Flaubert if he is right. ${ }^{25}$

\section{Conclusion}

Thus, in the end, cognitivism can be vindicated. We can indeed learn something from literature. Yet this something amounts to a general revelatory fact about the world or the human spirit matching what a literary author means via a certain true conversational implicature. This implicature is drawn from a fictionally true sentence that the author uses fictionally. Thus, properly speaking, what we learn from literature is what we learn from a literary author, i.e., a conjunction made of a certain general revelatory fact and by what she truly means, which matches that fact.

Acknowledgements This paper has been presented at the workshop Philosophy as/and/of Literature, University of Padua, December 14-15, 2017, Padua, and at the Philosophy Research Seminar, University of Auckland, March 21, 2018, Auckland. I thank all participants for their stimulating remarks. I also thank Carola Barbero, Manolo Garcia-Carpintero, and Fred Kroon for the insightful discussions had with them on this topic.

Funding Open access funding provided by Università degli Studi di Torino within the CRUI-CARE Agreement.

Open Access This article is licensed under a Creative Commons Attribution 4.0 International License, which permits use, sharing, adaptation, distribution and reproduction in any medium or format, as long as you give appropriate credit to the original author(s) and the source, provide a link to the Creative Commons licence, and indicate if changes were made. The images or other third party material in this article are included in the article's Creative Commons licence, unless indicated otherwise in a credit line to the material. If material is not included in the article's Creative Commons licence and your intended use is not permitted by statutory regulation or exceeds the permitted use, you will need to obtain permission directly from the copyright holder. To view a copy of this licence, visit http://creativecommons.org/licen ses/by/4.0/.

\footnotetext{
${ }^{25}$ Once things are put in this way, one can clearly distinguish between what a fictionally used sentence fictionally entails (cf. fn.17) and what it actually implicates. Notoriously, the fictionally used sentence of Manzoni's The Betrothed "The miserable girl replied" fictionally entails "Gertrude, the Monza's nun, had an intimate (sexual) relationship with Egidio, a mischievous guy." When truth-conditionally interpreted in the narrow fictional context that has the world of The Betrothed as its world, both sentences are indeed true in that world, hence they are fictionally true. Yet what at most Manzoni conversationally implied and that we learn from him as the author of The Betrothed is instead the actually true "Sadly enough, women in XVII Century Lombardy were forced to repress their sexuality by being induced to become nuns.".
} 


\section{References}

Åkerman, J. (2015). Infelicitous cancellation: The explicit cancellability test for conversational implicature revisited. Australasian Journal of Philosophy, 93, 465-474

Barbero, C. (2017). Aprender de la Imaginación. Hybris, 8, 129-141.

Bonomi, A. (2008). Fictional contexts. In P. Bouquet et al (Ed.), Perspectives on contexts (pp. 215250). CSLI.

Currie, G. (1990). The nature of fiction. Cambridge University Press.

Currie, G. (1998). Realism of character and the value of fiction. In J. Levinson (Ed.), Aesthetics and Ethics: Essay at the Intersection. (pp. 161-181). Cambridge University Press.

Currie, G. (2010). Narrative and narrators. A Philosophy of Stories. Oxford University Press.

Diffey, T. J. (1995). What can we learn from art? Australasian Journal of Philosophy, 73, 204-211.

Engel, P. (2016). Literature and practical knowledge. Argumenta, 2, 55-76.

Evans, G. (1982). The varieties of reference. Clarendon Press.

Everett, A. (2013). The nonexistent. Oxford University Press.

Frege, G. (1892). Über Sinn und Bedeutung. Zeitschrift für Philosophie und Philosophische Kritik 100, 25-50. Translated by M. Black as On Sense and Reference. The Philosophical Review, 57(1948), 209-230.

Friend, S. (2014). Believing in stories. In G. Currie et al (Eds.), Aesthetics and the Sciences of Mind (pp. 228-248). Oxford University Press.

Friend, S. (2017). The real foundation of fictional worlds. Australasian Journal of Philosophy, 95, 29-42.

Garcia-Carpintero, M. (2013). Norms of fiction-making. British Journal for Aesthetics, 53, 339-357.

Garcia-Carpintero, M. (2016). To tell what has happened from invention: Literature and philosophy on learning from fiction. In A. Selleri \& P. Gaydon (Eds.), Literary Studies and the Philosophy of Literature. (pp. 123-147). Springer.

Garcia-Carpintero, M. (2019). Assertions in fictions: An indirect speech act account. Grazer Philosophische Studien, 96, 445-462.

Gaut, B. (2005). Art and knowledge. In J. Levinson (Ed.), The Oxford handbook of aesthetics. (pp. 436-450). Oxford University Press.

Gendler, T. Z. (2000). The puzzle of imaginative resistance. Journal of Philosophy, 97, 55-81.

Green, M. (2017). Narrative fiction as a source of knowledge. In P. Olmos (Ed.), Narration as argument. (pp. 47-61). Springer.

Gibson, J. (2007). Fiction and the weave of life. Oxford University Press.

Grice, P. (1989). Studies in the way of words. Harvard University Press.

Huemer, W. (2007). Why read literature? In J. Gibson et al (Eds.), A Sense of the World: Essays on fiction, narrative, and knowledge (pp. 233-245). Routledge.

Ichino, A. and Currie G. (2017). Truth and trust in fiction. In E. Sullivan-Bissett et al (Eds.), Art and Belief (pp. 63-82). Oxford University Press.

Kaplan, D. (1989). Demonstratives. In J. Almog et al (Eds.), Themes from Kaplan (pp. 481-563). Oxford University Press.

Kivy, P. (2011). Once-told tales: An essay in literary aesthetics. Blackwell.

Kroon, F. and Voltolini, A. (2018). Fictional entities. In E. Zalta (Ed.), The Stanford Encyclopedia of Philosophy, https://plato.stanford.edu/archives/fall2018/entries/fictional-entities. Accessed 25 Apr 2021.

Lamarque, P., \& Olsen, S. H. (1994). Truth, fiction, and literature. Clarendon Press.

Lewis, D. (1978). Truth in fiction. American Philosophical Quarterly, 15, 37-46.

Nanay, B. (2010). Imaginative resistance and conversational implicature. The Philosophical Quarterly, 60, 586-600.

Nussbaum, M. C. (1990). Love's knowledge. Oxford University Press.

Paolucci, C. (2017). Whereof one cannot theorize, thereof one must narrate. In T. Thellefsen \& B. Sørensen (Eds.), Umberto Eco in His Own Words. (pp. 165-174). De Gruyter.

Popa-Wyatt, M. (2014). Pretence and echo: Towards an integrated account of verbal irony. International Review of Pragmatics, 6, 127-168.

Predelli, S. (1997). Talk about fiction. Erkenntnis, 46, 69-77.

Predelli, S. (1998). I am not here now. Analysis, 58, 107-115.

Predelli, S. (2005). Contexts. Oxford University Press. 
Predelli, S. (2017). Proper names: A Millian account. Oxford University Press.

Predelli, S. (2020). Fictional discourse. Oxford University Press.

Putnam, H. (1976). Literature, science, and reflection. New Literary History, 3, 483-491.

Putnam, H. (1987). The many faces of realism. Open Court.

Recanati, F. (2000). Oratio Obliqua, Oratio Recta. The MIT Press.

Reicher, M. (2012). Knowledge from fiction. In J. Dauber et al (Eds.), Understanding Fiction (pp. 114-132). Mentis.

Rowe, M. (1997). Lamarque and Olsen on literature and truth. The Philosophical Quarterly, 47, 322-341.

Russell, B. (1940). An inquiry into meaning and truth. Allen and Unwin.

Saul, J. (2010). Speaker-meaning, conversational implicature and calculability. In K. Petrus (Ed.), Meaning and analysis: New analyses on Grice. (pp. 170-183). Palgrave.

Searle, J. (1975). The logical status of fictional discourse. New Literary History, 6, 319-332.

Stolnitz, J. (1992). On the cognitive triviality of art. British Journal of Aesthetics, 32, 191-200.

Voltolini, A. (2006). Fiction as a base of interpretation contexts. Synthese, 153, 23-47.

Voltolini, A. (2016). The nature of fiction/al utterances. Kairos, 17, 28-55.

Voltolini, A. (2021). Real authors and fictional agents (fictional narrators, fictional authors). Organon $F, 28,60-75$.

Walton, K. L. (1990). Mimesis as make-believe. Harvard University Press.

Weitz, M. (1943). Does art tell the truth? Philosophy and Phenomenological Research, 3, 338-348.

Wittgenstein, L. $\left(2009^{4}\right)$. Philosophical investigations. Blackwell.

Publisher's Note Springer Nature remains neutral with regard to jurisdictional claims in published maps and institutional affiliations. 